Новые подходы должны быть направлены, прежде всего, на привлечение местного потенциала и участников, а не на повышение ожиданий в отношении иностранной помощи, войск и обучения со стороны США.

$$
* * *
$$

1. Peter Duignan and L. H. Gann, The United States and Africa: A History Cambridge: Cambridge University Press. 1984.

2. The Spanish American War. URL: https://history.state.gov/milestones/1866-1898/spanish-american-war (дата обращения 15.01.2021).

3. The Atlantic Charter. URL: http://www.history.com/topics/world-war-ii/atlantic-charter (дата обращения 18.01.2021).

4. Text of Atlantic Charter. URL: https://www.history.com/topics/world-war-ii/atlantic-charter (дата обращения 23.01.2021).

5. Lions on the move II: Realizing the Potential of Africa's Economies, 2016. McKinsey Global Institute.URL: https://www.mckinsey.com/featured-insights/middle-east-and-africa/lions-on-the-moverealizing-the-potential-of-africas-economies (дата обращения 24.01.2021).

6. Douglas I. Understanding Trump's Trade War // Foreign Policy. Winter 2019. URL: https://foreignpolicy.com/gt-essay/understanding-trumps-trade-war-china-trans-pacific-nato/ (дата обращения 19.01.2021).

7. Renshon S. A., Suedfeld P (Ed).The Trump Doctrine and the Emerging International System. Palgrave Macmillan. 2020. 432 p.

8. US Secretary of Commerce Wilbur Ross, announces $\$ 1$ billion in deals during Africa mission. US Department of Commerce. 06 July 2018. URL: https://agoa.info/news/article/15465-us-secretary-ofcommerce-wilbur-ross. (дата обращения 16.01.2021).

9. Statement by Acting Assistant Secretary of State for Africa Daniel Yamamoto, "Political Crisis in the Democratic Republic of the Congo". US House of Representatives, Foreign Affairs Subcommittee on Africa, Hearing, November 9, 2017.

10. Remarks by Assistant Secretary of State Tibor Nagy, https://www.state.gov/baker-institute-for-publicpolicy-at-rice-university (дата обращения 22.01.2021).

11. Overview . US International Development Finance. URL: Corporation URL: https://www.dfc.gov/whowe-are/overview (дата обращения 11.01.2021).

12. Deputy Secretary of State John J. Sullivan, "Counterterrorism Efforts in Africa". US House of Representatives, Committee on Foreign Affairs, Hearing, December 7, 2017.

13. Center for Strategic and International Studies, "U.S. Economic Engagement in Africa: Making Prosper Africa a Reality" (Washington, DC, April 2019).

14. New York Times, "Niger Approves Armed U.S. Drone Flights, Expanding Pentagon's Role in Africa," November 30, 2017.

15. Office of the Secretary of Defense, FY2020 Justification for Component Contingency Operations, the Overseas Contingency Operation Transfer Fund (OCOTF), May 2019.

16. Hearing before the Senate Armed Services Committee, U.S. Africa Command and Southern Command, February 7, 2019.

17. Force Times, "Armed Drones to Fly Out of Niger Air Base Now Operational After Delayed Completion," November 1, 2019.

18. Conley R.S. Donald Trump and American Populism: New Perspectives on the American Presidency.Published by: Edinburgh University Press. 2020. 372 p.

19. U.S. Counterterrorism Priorities and Challenges in Africa. Congressional Research Service TE10044 December 16, $2019 \quad$ URL: https://crsreports.congress.gov/search/\#/2?termsToSearch=africa\&orderBy=Relevance (дата обращения 25.01.2021).

\title{
Ali Abdirahman Ahmed Extremism as a threat to the national security of Somalia
}


order to establish a society based on its rigid interpretation of Shariah law. Although based in Somalia, Al Shabaab also conducts attacks in neighboring countries, notably Kenya. Al Shabaab emerged as an independent organization around December 2006 after breaking away from the Islamic Courts Union (ICU), for which it had served as the military wing. Since the late 2000s, Al Shabaab has had close ties to Al Qaeda and other external extremism groups and has sought to frame the Somali struggle as part of a global jihadist movement. The group has engaged in bombings, suicide attacks, and armed assaults, especially against Somali government targets, private civilians, Christians, diplomats, foreign troops, and nongovernmental organization or aid workers .

Key words: Al-shabab, The Islamic State in Somalia (ISS).

\section{Introduction}

Since September 11, failed states such as Afghanistan have been viewed as significant security threats. Menkhaus' probing analysis of Somali dynamics in the last decade suggests this is only partially true. Key Somali elites, with few incentives to revive a central government, benefit from the current state of collapse, and such collapse need not be associated with lawlessness or economic stagnation. Indeed, commercial elites have successfully reined in the worst warlord excesses to promote highly profitable pockets of stability, and Somalia has proven to be inhospitable terrain for foreign terrorist groups, who need some kind of complicit central authority for their own security. Perhaps this argument will convince Western decision-makers to once again consign Somalia to the benign neglect it knew before September 11. Rather than try to rebuild a central state in Somalia, a goal he views as too ambitious for the time being, Menkhaus recommends strengthening the groups that are promoting lawfulness and a modicum of prosperity even absent a central government.[1]

In the Global Terrorism Index (2018), Somalia was ranked sixth on the list of countries most impacted by terrorism in 2017.[2] Al-Shabaab, was behind the deadliest terrorist attack in 2017 worldwide, when a suicide bomber detonated an explosives-laden truck, killing 587 people, in Mogadishu on 14 October.[3] Al-Shabaab also carries out attacks in neighbouring countries, such as the mass shooting at Westgate shopping mall in Nairobi in 2013, the Garissa University College attack in 2015 and the attack on a corporate campus in Nairobi in January 2019. Although al-Shabaab has had several military setbacks since 2012,[4] these attacks - as well as frequent smaller attacks in and outside of Somalia demonstrate that the group still poses a significant threat to security and stability in the region.

Al-Shabaab is affiliated with and has pledged allegiance to al-Qaeda, and is listed as a terrorist organisation by many countries. Initially, al-Shabaab mainly had a national focus, aiming to take over power in Somalia. However, in recent years, the organisation has changed its profile stating that the Somali fight is also a part of a "global jihad". In addition to recruitment locally, the organisation has attracted members from western countries as well as other parts of eastern Africa. As the name al-Shabaab ("the youth") indicates, young people predominate in the group.

The total size of al-Shabaab is unclear, but it has been estimated that the organisation consists of between 7000 and 9000 people.[5] In 2014, Botha and Abdile published their study, "Radicalization and al-Shabaab Recruitment in Somalia",[6] based on interviews with close to 100 former al-Shabaab members. Of these interviewees, 91\% had joined before turning 30, and $40 \%$ joined between the ages of 15 and 19 .

The reasons why some young people choose to join al-Shabaab varies. For some, it is seen as a career opportunity and a way to support themselves and their families. Other motivations are grievances and revenge, religious convictions, increased status and power, seeking protection or adventure, or a combination of various factors. [7] Some are recruited by force. As members of al-Shabaab, many experience disillusionment with the group, the leadership, the cause or the methods employed.[8] Others find the salary they receive in al- 
Shabaab inadequate or have family obligations that make them want to return to civilian life.[9] Some seized the opportunity and disengaged after President Mohamed Abdullahi "Farmajo" Mohamed publicly announced, in April 2017, a 60-day amnesty for al-Shabaab fighters willing to give themselves up.[10] The question then arises: how to assist those who want out?

Al-Shabaab receives its funds from both external and internal sources, namely charcoal exports, taxation of local business people, and international jihadist support and their ties to the global jihadist movement generated income through the Arabian Peninsula and Kenya.

The militants collects more revenue than government, they collect at least $\$ 15 \mathrm{~m}$ (£11m) a month, with more than half the amount coming from the capital, Mogadishu, the Hiraal Institute said. Some businesses pay both the jihadists and the internationally recognised government. The group controls much of southern and central Somalia but has been able to extend its influence into areas controlled by the government based in Mogadishu.[11]

They also profit from foreign aid, refugees in Baidoa buy goods from local merchants using cash cards given to them by the UN. Al-shabab taxes local business, resulting in higher prices for goods, militants controls the key transit route in and out of Baidoa, and charges supply trucks and other vehicles a toll to use it, A single checkpoint generates up to $\$ 5,000$ a day. Some companies and aid groups are paying Al-shabab between \$25,000 and \$75,000 each month in exchange of their employees and infrastructure, the UN says.[12]

The report describes as "brutal" the way the group extracts money from the rural population. "Fear and a credible threat to their lives is the only motivation that drives alShabab taxpayers," the report says.[13]

\section{Al-shabab extremism}

Somali militant group al-Shabab recently said it does not intentionally target Muslims - but a new report indicates that whatever its intentions, the group has a lot of Muslim blood on its hands. More than 4,000 civilians have been killed in al-Shabab attacks since 2010, according to records compiled by the independent group Armed Conflict, Location and Event Data Project, or ACLED. The majority of the deaths were in Somalia - where the population is almost entirely Muslim - with smaller numbers stemming from attacks in Kenya, Uganda and Djibouti. More than 3,000 of the deaths have occurred since 2015.[14]

ACLED says the figure encompasses deaths from shooting attacks, abductions, suicide bombings, and other incidents in which civilians were "determined to be the direct, primary target." It excludes deaths from battles with the military or other armed groups, and bombing attacks primarily targeting security forces, ACLED says.

Al Shabaab, meaning "The Youth" in Arabic, is the largest militant organization fighting to oust the Somali government and the foreign military presence supporting it.[15] The group seeks to control territory within Somalia in order to establish a society based on its rigid interpretation of Shariah law. Although based in Somalia,

Al Shabaab also conducts attacks in neighboring countries, notably Kenya. Al Shabaab emerged as an independent organization around December 2006 after breaking away from the Islamic Courts Union (ICU), for which it had served as the military wing. Since the late 2000s, Al Shabaab has had close ties to Al Qaeda and has sought to frame the Somali struggle as part of a global jihadist movement. The group has engaged in bombings, suicide attacks, and armed assaults, especially against Somali government targets, Christians, private civilians, foreign troops, diplomats, and aid or nongovernmental organization workers.[16]

Formed on in December 2006, Group is active. First Attack was March 26, 2007: A man named Adam Salam Adam used a car bomb to conduct a suicide attack against Ethiopian soldiers in Mogadishu. Al Shabaab claimed responsibility for the bombing, allegedly the city's first suicide attack. ( $\sim 73$ killed, unknown wounded).[17], and Last Attack was 2 jan 2021 several people killed in attack on Turkish company in Somalia. Al-shabab claimed 


\section{responsibility for the blast near Somali capital Mogadishu that killed at least five peaple and injures 14.[18] \\ Islamic state extremism}

The Islamic State in Somalia (short: ISS) or Abnaa ul-Calipha is an Islamic State of Iraq and the Levant-affiliated group that primarily operates in the mountainous areas of Puntland, though has also claimed responsibility for several terrorist attacks throughout the rest of Somalia. Led by Sheikh Abdul Qadir Mumin, the group is estimated to have up to 300 active fighters. Since its formation, ISS probably managed to take control of a small, sparsely populated territory in northern Somalia's mountainous hinterland, though it was not acknowledged as official province ("Wilayat") by ISIL's central leadership until December 2017. Since then, it has sometimes been called Somalia Province ("Wilayat al Somal") by pro-ISIL media. ISS is also the declared enemy of al-Shabaab, which considers the Islamic State a significant threat to its own predominance among Jihadist factions in Somalia.

The group also grew more sophisticated and further expanded its presence throughout Somalia. It had begun to collect taxes (essentially protection money) on businesses in Bosaso by August 2018, greatly increasing its revenue.At some point in 2018, ISS managed to convince a significant number of al-Shabaab militants to defect, resulting in the formation of an Islamic State cell in Beledweyne. As result of its increasing activity in central and southern Somalia, the rivalry between ISS and al-Shabaab reignited in full, with several clashes occurring between the groups. In October 2018, Al-Shabaab probably executed ISS depuy Mahad Maalin in Mogadishu, while Islamic State forces ambushed an al-Shabaab group near B'ir Mirali southwest of Qandala, reportedly killing 14 rival militants. The growing violence between the two jihadist rebel factions resulted in al-Shabaab central command releasing a speech as well as an 18-page treatise on 20 December 2018. In these works, the Islamic State was sharply rebuked as corrupt, apostate, and seditionist force, while al-Shabaab authorized its loyalists to destroy ISS elements as "disease in the Jihad". This amounted to an official declaration of war. [19]

By October 2016, ISS had claimed less than one dozen attacks overall since its foundation, showing that the group was still relatively weak. Nevertheless, the fact that many of these strikes had taken place in Mogadishu, indicated that ISS had become able to operate throughout wider Somalia, not just in its core regions in Puntland. Experts also estimated that Mumin's cell had significantly grown to up to 300 fighters. On 26 October, the group eventually launched their first major operation by targeting the major port town of Qandala. The town had both symbolic as well as strategic significance, as it could allow ISS to bolster their local support and receive more supplies from Yemen. The Islamic State fighters managed to overrun the town, meeting little resistance, and thereafter controlled it largely unchallenged until 3 December. On that day, the Puntland Security Force launched a counteroffensive, and after sporadic fighting for four days, retook Qandala on 7 December 2016. Mumin's men were forced to retreat to El Ladid, a village 30 kilometers south of Qandala, where government forces once again attacked and scattered them on 18 December. Overall, ISS suffered numerous casualties during the Qandala campaign, but had scored a symbolic victory nonetheless, having captured and held a major town for more than a month. Having established a new headquarters in the al-Mishkat Mountains, ISS subsequently managed to attract new recruits, mostly children and orphans, though also some new defectors from al-Shabaab. It also became generally more active.[20]

\section{Conclusion}

For over a decade, the United States has considered the Horn of Africa-Eritrea Kenya, Djibouti, Ethiopia, Sudan and Somalia a major source of terrorism.

Thus Extremism are threat to the national security of Somalia due to rise in power, extended terrorist attacks, there military strength, propaganda, bombing civilians and announcement of extremis militants. And carries out attacks in neighbouring countries, such as the mass shooting at Westgate shopping mall in Nairobi in 2013, the Garissa University 
College attack in 2015 and the attack on a corporate campus in Nairobi in January 2019. Although al-Shabaab has had several military setbacks since 2012.Al Shabaab has had close ties to Al Qaeda and other external extremism groups and has sought to frame the Somali struggle as part of a global jihadist movement. The group has engaged in bombings, suicide attacks, and armed assaults, especially against Somali government targets, private civilians, Christians, diplomats, foreign troops, and nongovernmental organization or aid workers .

$$
* * *
$$

1. Somalia: State Collapse and the Threat of Terrorism By International Institute for Strategic Studies

2. The Institute for Economics and Peace (2018) 'Global Terrorism Index 2018. Measuring the Impact of Terrorism', IEP report, Available at: <http://globalterrorismindex.org/>

3. Ibid., pp. 4 and 10.

4. Hansen, Stig Jarle (2013) Al-Shabaab in Somalia. The History and Ideology of a Militant Islamist Group 2005-2012. London: Hurst.

5. BBC News (2017) 'Who are Somalia's al-Shabab?', BBC News World - Africa, 22 December, Available at: 〈https://www.bbc.com/news/world-africa-15336689>

6. Botha, Anneli and Abdile, Madhile (2014) 'Radicalization and Al-Shabaab Recruitment in Somalia', ISS Paper 266, Available at: 〈https://issafrica.s3.amazonaws.com/site/uploads/Paper266.pdf>

7. Khalil, James, Brown, Rory, Chant, Chris, Olowo, Peter and Wood, Nick (2019) 'Deradicalisation and Disengagement in Somalia. Evidence from a Rehabilitation Programme for Former Members of AlShabaab', RUSI Whitehall Report 4-19, Available at: <https://rusi.org/publication/whitehallreports/deradicalisation-and-disengagement-somalia-evidence-rehabilitation>; Hansen, Stig Jarle (2013) op. cit.; and Botha, Anneli and Abdile, Madhile (2014) op. cit.

8. Botha, Anneli (2017) 'Rehabilitation and Reintegration of Former Al-Shabaab Fighters in Somalia', RIMA Occasional Papers 5, No. 25, Available at: $<$ https://muslimsinafrica.wordpress.com/2017/12/04/rehabilitation-and-reintegration-of-former-alshabaab-fighters-in-somalia-dr-anneli-botha/>

9. Khalil, James et al (2019) op. cit.

10. BBC News (2017) 'Al-Shabab Fighters Offered Amnesty as New Somali President Declares War', BBC News World - Africa, 6 April, Available at: <http://www.bbc.com/news/world-africa-39513909>; and Khalil, James et al (2019) op. cit.

11. https://www.bbc.com/news/world-africa-54690561

12. https://edition.cnn.com/2018/02/12/africa/somalia-al-shabaab-foreign-aid-int//index.html

13. https://www.bbc.com/news/world-africa-54690561

14. https://www.voanews.com/africa/al-shabab-attacks-killed-4000-past-decade-says-data-gathering-group

15. "Who are al-Shabab?" Al Jazeera. 4 Aug. 2009. Web.1 July 2013.

16. Al Shabaab- Al Shabaab is an affiliate organization of $\mathrm{Al}$ Qaeda based in Somalia. <https://cisac.fsi.stanford.edu/mappingmilitants/profiles/al-shabaab>.

17. Harnisch, Christopher."The Terror Threat from Somalia: The Internationalization of Al Shabaab." Critical Threats Project, American Enterprise Institute, 12 Feb. 2010. Web. 20 Aug 2015.

18. Aljazeera <https://www.aljazeera.com/news/2021/1/2/several-people-killed-in-attack-on-turkishcompany-in-somalia>

19. Islamic State of Somali<https://en.wikipedia.org/wiki/Islamic_State_in_Somalia>

20. https://en.wikipedia.org/wiki/Islamic_State_in_Somalia

\section{Ali Abdirahman Ahmed National security of Somalia and it's challenges \\ Southern Federal University (Russia, Rostov-on-Don)}

doi: $10.18411 / l j-02-2021-273$

idsp: ljournal-02-2021-273

\section{Abstract}

Ongoing armed conflict, insecurity, lack of state protection, and recurring humanitarian crises exposed Somali civilians to serious abuse. There are an estimated 2.6 million internally displaced people (IDPs), many living unassisted and vulnerable to abuse. 